\title{
The FAIL TO construction: A contrastive perspective
}

\author{
Thomas Egan \\ Inland Norway University of Applied Sciences (Norway)
}

\begin{abstract}
This article considers the various senses of the English FAIL TO construction in the light of its Norwegian translation correspondences. This construction has been alleged to be in the process of grammaticalising as a marker of negation in Present-day English. The paper tests the hypothesis that if FAIL TO is in the process of grammaticalising as a marker of negation pure and simple, we should find it used to translate, or find it translated by, pure negation markers (the equivalent of English not) in other languages. The particular language of translation investigated in this paper is Norwegian in which the default negation marker is ikke. It is shown that translations in both directions lend support to the hypothesis.
\end{abstract}

Keywords: failure, periphrastic negation, inherent negation, grammaticalisation, English/ Norwegian

\section{Introduction}

The topic of this article is the construction consisting of the verb fail followed by a toinfinitive, the FAIL TO construction. This construction may be used with several, to some extent related, senses. Three main senses are listed in the Oxford English Dictionary (OED), "to be unsuccessful in an attempt or exercise' (sense 12a), 'to leave undone, omit to perform" (sense 10a), and "not to have the effect of" (sense 10c). The first of these senses will be referred to in this article as the Effort sense, the second as either the Duty or Expectation sense, and the third as the Negation sense. The decision to distinguish between two separate sub-senses of 'omit to perform' is prompted by the conviction that there is a germane distinction between omitting to carry out an action the subject has a duty to perform and omitting to carry out an action that the speaker/writer was expecting the subject to perform, without the subject being independently bound to do so. Note that the corpus-based The New Oxford Dictionary of English (Pearsall \& Hanks 1988) distinguishes the two senses, defining them as 'neglect to do something' and 'behave in a way contrary to hopes or expectations by not doing something', respectively. The four senses of FAIL TO are illustrated by (1)-(4), the first of which encodes implied unsuccessful effort, the second implied neglected duty, the third implied disappointed speaker expectation, and the fourth negation pure and simple. All four are taken from the English-Norwegian Parallel Corpus (ENPC: see section 2). 
(1) It was a deep disappointment to him when the Scots failed to gain their objectives... $(\mathrm{MH} 1)^{1}$

(2) If a Member State persists in failing to put into practice the recommendations of the Council... (MAAS1)

(3) Incredibly, even now the German High Command failed to perceive either the invasion fleet or the significance of the massive Allied activity. (MH1)

(4) Another family of ceratoids fails to develop large nostrils .... (SJG1)

It has been suggested by various scholars, including Mackenzie (2008) and Egan (2010, 2016) that the FAIL TO construction as instantiated by instances like (4) is undergoing grammaticalisation. If this is the case one might hypothesise that it would be frequently translated by sentences containing pure negation markers, for instance the default Norwegian negation marker ikke ('not'). However, one would not expect FAIL TO to be employed to the same extent as a translation of Norwegian ikke, since the default means of coding negation in English is by means of expressions containing not. One would therefore hypothesise that there would be more instances of the FAIL TO construction in the English original texts than the English translations. It is these two hypotheses that form the backbone of this article, which explores the question of how instances of FAIL TO in original English texts in the ENPC are translated into Norwegian, and what sort of expressions in original Norwegian texts are translated into English by FAIL TO. The motivation for the study is the wish to test whether or not the contention that FAIL TO is functioning in Present-day English in at least some contexts as a negation marker is supported by the evidence of the translation corpus.

The article is structured as follows: section 2 introduces the corpus, the search queries and criteria for categorising the instances into the semantic categories employed in the analysis. Section 3 contains a brief discussion of the concepts of negation and grammaticalisation, as these may apply to the FAIL TO construction. Section 4 presents the results of the corpus search and the analysis of the translations from and into English. Finally, section 5 contains a summary and conclusions.

\section{The corpus, queries and criteria for analysis}

The data for the present study comprise all instances of the FAIL TO construction in both original English texts and English translations in the English-Norwegian Parallel Corpus (ENPC: see Johansson 2007). The ENPC contains extracts from 50 English and 50 Norwegian original texts, 30 fictional and 20 non-fictional, with their translations into the other language. ${ }^{2}$ All instances of the lemma FAIL were extracted. The reason for not restricting the search to instances of FAIL TO was the possibility of there being examples with adverbials intervening between the matrix verb and the infinitive marker. In fact there is only one such example, in the English original texts, cited here as (5).

(5) That this was the landing, they failed for many days to understand. (MH1)

At det var den virkelige landsettingen, gikk ikke opp for dem før flere dager senere. (MH1T)

“...they did not realise..."

\footnotetext{
${ }^{1}$ (MH1) indicates the provenance of the token, 'MH' being the initials of the author. (MH1T) would serve to indicate a translation of the same text, ' $\mathrm{T}$ ' standing for 'translation'.

${ }^{2}$ For details of the corpus texts see <http://www.hf.uio.no/ilos/english/services/omc/enpc/>.
} 
Having downloaded the relevant instances, I classified them into the four categories introduced in section 1, Effort, Duty, Expectation and Negation. The classification was based on the answers to the following three questions:

(i) Does the predication involve the expenditure of effort on the part of the subject?

(ii) If no effort is involved, does the complement clause encode a situation which the subject had an objective duty to realise?

(iii)If there is no connotation of either effort or duty, does the complement clause encode a situation which the speaker indicates he or she would expect to have been realised?

Since the classification was made by just one researcher, the results were set aside and the analysis of the instances repeated independently after a three-month interval, with any instances placed in a different category, of which there were a handful, subjected to closer analysis.

With respect to the first question, the identification of the presence or absence of an element of effort on the part of the syntactic subject does not as a rule pose any problems for the analyst. (6) may stand as a representative example.

(6) He believed that the reason he had failed to win the girl was because all along he had been too timid, too sensitive, too afraid of rejection, pain, ridicule and loss of face. (RF1)

Han mente at grunnen til at han ikke hadde klart å vinne piken var at han hele veien hadde vært for sky, for nærtagende, for redd for avvisning og smerte, for å bli holdt for narr eller tape ansikt. (RF1T)

"...had not managed to..."

There can be no doubt that the subject in (6) made an objective effort to gain the affections of the girl. As well as instances like (6), where it is the subject that is the source of the effort, there are also instances in which, while there is obviously an expenditure of effort, there is a metonymic relationship between the syntactic subject and the person or persons who are making the effort. (7) is a typical example of such a relationship.

(7) The drive for Cherbourg had thus failed to achieve its principal strategic purpose, and when the Americans renewed their attack southwards, they made slow progress through the bocage. (MH1)

Kampen om Cherbourg hadde dermed ikke nådd sitt viktigste strategiske mål, og da amerikanerne fornyet angrepene sørover, gikk det langsomt over bocage-landskapet. (MH1T)

"...had not reached..."

Instances like (7) were classified as instantiating Effort FAIL TO. (6) and (7) are objective in the sense of Traugott (2010), since the lack of success encoded in both examples is not related to the attitude of the speaker. ${ }^{3}$ Duty FAIL TO, which the second question is aimed at identifying, resembles Effort FAIL TO in this respect. It is exemplified here by (8).

\footnotetext{
${ }^{3}$ I write 'in the sense of Traugott', since Langacker (2008, for example) has promulgated an influential, but quite different, interpretation of what constitutes subjectivity.
} 
(8) As long as a Member State fails to comply with a decision taken in accordance with paragraph 9, the Council may decide to apply the following measures: (MAAS1) Så lenge en medlemsstat ikke etterkommer et vedtak etter nr. 9, kan Rådet bestemme å ta i bruk eller skjerpe ett eller flere av følgende tiltak: (MAAS1T) "...does not comply with..."

It is clear in (8) that the member states in question are duty bound to comply with the relevant decisions. It is not simply the case that the speaker would expect them to do so, although of course it may well be considered the norm for parties to fulfil their legal obligations. The existence of such an external, objective requirement is generally easy to recognise.

The third question is aimed at identifying examples of the Expectation sense of FAIL TO. This sense, in which it is merely the predictions of the speaker that are disappointed, is characterised by the absence of any element of either effort or duty. Consider in this respect example (9).

(9) Certainly he had a strong streak of solipsism in him, but surely not so strong that he would have failed to notice a riot going on around him. (RF1)

Riktignok var han mye av en solipsist, men avgjort ikke så mye at han ikke ville lagt merke til at det foregikk opptøyer rundt ham. (RF1T) "...would not have noticed..."

In (9) the speaker expresses surprise (surely not so strong that) at the idea that the subject would have failed to notice the riot in question. There is no implication that the subject had made a conscious effort to do so, nor that he had any duty to do so. There is, nonetheless, no doubt that the speaker would have expected him to do so. Expectation FAIL TO is subjective, in the sense of Traugott (2010), in that it is only the expectations of the speaker that are disappointed.

The final sense of the FAIL TO construction, which will be discussed in more detail in section 3, is the Negation sense, exemplified here by (10). It is characterized by the absence, not only of any element of effort on the part of the subject, or the existence of a duty which the subject neglects to fulfil, but also by the absence of any connotation of expectation on the part of the speaker. In other words, if the answer to all three questions posed by the analyst is 'no', the token is classified as an example of Negation FAIL TO.

(10) To human eyes many of the body markings appear to be beautiful and highly conspicuous, but this is because we so often see them in artificial environments where their camouflage quality fails to show itself. (DM1)

I menneskets øyne virker mange av forsvinningsdraktene både vakre og svært iøynefallende, men det skyldes at vi så ofte ser dem i kunstige omgivelser der deres kamuflasjeeffekt ikke kommer til sin rett. (DM1T)

"...does not prove of use..."

There is no implication in (10) that the speaker would expect the camouflage quality to show itself. Section 4.1 contains details of how many of the four types of FAIL TO are found in the original English texts and in the translations from Norwegian. 


\section{FAIL TO, negation and grammaticalisation}

Millions of words have been written about the concept of negation, which raises many thorny questions for philosophers as well as linguists (see, for instance, the introduction to Horn 2001). Indeed, it is by no means certain that an answer can be found to many of these questions since, according to Dixon (2012), "Negation is an intrinsic notion in the world, and in language. It is not something which can be defined or even explained." (Dixon 2012: 89) In the present section, however, I will adopt a common-sense definition of negation as encoding the non-realisation of some situation or other. This simple definition would, I imagine, meet with general approval, at least in cases of predications that do not involve irony or sarcasm.

The present article is not the first to touch on the topic of FAIL TO as encoding negation in the texts in the ENPC. Johansson (1997: 205) discusses the following example.

(11) Men jeg greidde visst ikke [lit. did not manage] å få det forklart. (KF1) But apparently I failed to make her understand. (KF1T)

Johansson includes this example under the heading of 'Implicit Negation' and states that in such examples the English verb "can be described as semantically negative". Various scholars employ terms equivalent to 'Implicit Negation' to describe the sort of negation coded by FAIL TO. Karttunen (1971) speaks in terms of negative implicativity, Dixon (2012: 124) employs the term 'inherent negativity', while Huddleston and Pullum (2002: 835) refer to fail as one of a class of 'covertly negative lexical items with clausal or clause-like complements'. Other such verbs they mention are avoid, decline, forget, neglect and refrain.

The description of the sort of negation coded by FAIL TO as implicit, inherent or covert is prompted by the fact that it does not contain a negative particle like not. It rests, in other words, on formal grounds. One might, on the other hand, argue that functionally the construction is maximally explicit, since the situation in the complement clause is never ever realised. It differs in this respect from forget, which entails the non-realisation of a situation when followed by a to-infinitive complement, but its realisation when followed by an -ing complement (see Egan 2008: 286). Rather than say that FAIL TO implies negation, one could argue that it entails negation and may, in addition, imply effort, duty or expectation. Indeed, Bolinger writes that fail codes 'categorical negation', giving as an example "There failed to appear (there did not appear) the very one we needed most" (Bolinger 1977: 122). This ability of FAIL TO to occur with there as subject is taken by Mackenzie as evidence that fail is a subject-raising verb. Mackenzie also provides evidence of its negative character. He points out that fail is not independently modifiable by an adverbial when it occurs in Negation FAIL TO and that it tends to occur with negative polarity items (Mackenzie 2008: $61)$.

According to Dixon "Recent work had provided a number of tests for whether a sentence in English should be considered negative - addition of a positive tag, or an addition commencing with and neither, or one commencing with not even" (Dixon 2012: 93). Egan (2010) used the and neither test to investigate whether the matrix verb FAIL TO is backgrounded at the expense of the complement predicate. Boye and Harder $(2009,2012)$ maintain that this sort of discursive backgrounding is typical of the process whereby a formerly lexical element acquires grammatical status. Egan (2010) contains evidence of discursive backgrounding in the form of a selection of corpus tokens in which phrases like ' $\mathrm{x}$ failed to do something' are followed by 'and neither did y'. 
Given that FAIL TO functions to all intents and purposes as a pure negation marker in at least some contexts, the question naturally arises as to how this usage has come about. According to Mackenzie, "If the lexical verb fail lends itself to a usage which is entirely equivalent to the grammatical strategy of negation, this suggests that, in this usage, it has been subject to a degree of grammaticalization" (Mackenzie 2008: 54). The development of a negation maker from a verb such as fail is by no means unusual in the world's languages, as attested by Dixon (2012: 94). Traugott and Dasher (2002) describe grammaticalisation as being "properly conceived as the change whereby lexical material in highly constrained pragmatic and morphosyntactic contexts is assigned functional category status, and where the lexical meaning of an item is assigned constructional meaning" (Traugott and Dasher 2002: 81). According to Diewald, "the process of grammaticalization is a process whereby linguistic items gain grammatical function while reducing their lexical-descriptive function" (Diewald 2010: 18). We have seen that there are contexts in which FAIL TO displays functional as opposed to lexical content. This shows that FAIL TO is grammatical; there remains the question of when it has been grammaticalised.

There are, to the best of my knowledge, no instances of Negation FAIL TO in Middle English. I write 'to the best of my knowledge' since the fact that FAIL TO was itself almost invariably negated before Late Modern English (the earliest non-negated example in the OED is from 1810), with two morphemes encoding non-realisation of the complement situation, one of which serves to cancel the other, renders inappropriate the sort of tests which are normally applied to determine the presence of negation. According to Mackenzie the "notion of disappointed expectation plays a crucial role in the understanding of how fail has come to be used" (Mackenzie 2008: 55). It does, indeed, seem more likely that it is the bleaching of the element of speaker expectation that has resulted in FAIL TO functioning as a negation marker. In addition to instantiating semantic attrition of the element of speaker expectation, Negation FAIL TO instantiates attrition of the element of subjectivity itself. Kranich (2010: 118) maintains that while in the early stages of grammaticalization "the newly emerging constructions are often made use of by speakers to express subjective shades of meanings, such meanings tend to get lost in later stages of grammaticalization". While it would be overstating the case to say that FAIL TO is in the later stages of grammaticalization, it certainly exhibits, in examples of Negation FAIL TO, the sort of loss of subjective shades of meaning to which Kranich is referring.

\section{Contrastive analysis}

Since the goal of this paper, as stated in the introduction, is to investigate the translation correspondences of FAIL TO in order to cast light on whether the construction has come to be used to encode negation pure and simple, the presentation of the Norwegian expressions in this section will concentrate on their function in holding up a mirror to their English correspondences, rather than the semantics of these expressions in their own right. The section is divided into three parts. Section 4.1 presents the overall results for the verb FAIL in all three constructions in which it is commonly employed, in both original English texts and translations into English. Section 4.2 looks more closely at Norwegian translations of the English instances of FAIL TO and section 4.3 at the use of FAIL TO in English translations of Norwegian originals. 


\subsection{The overall results}

The number of instances of FAIL TO in both original English texts and translations into English are shown in Figure 1, which also includes totals numbers of the other two constructions containing FAIL, the intransitive construction and the construction with a nominal object (see examples 12-13).

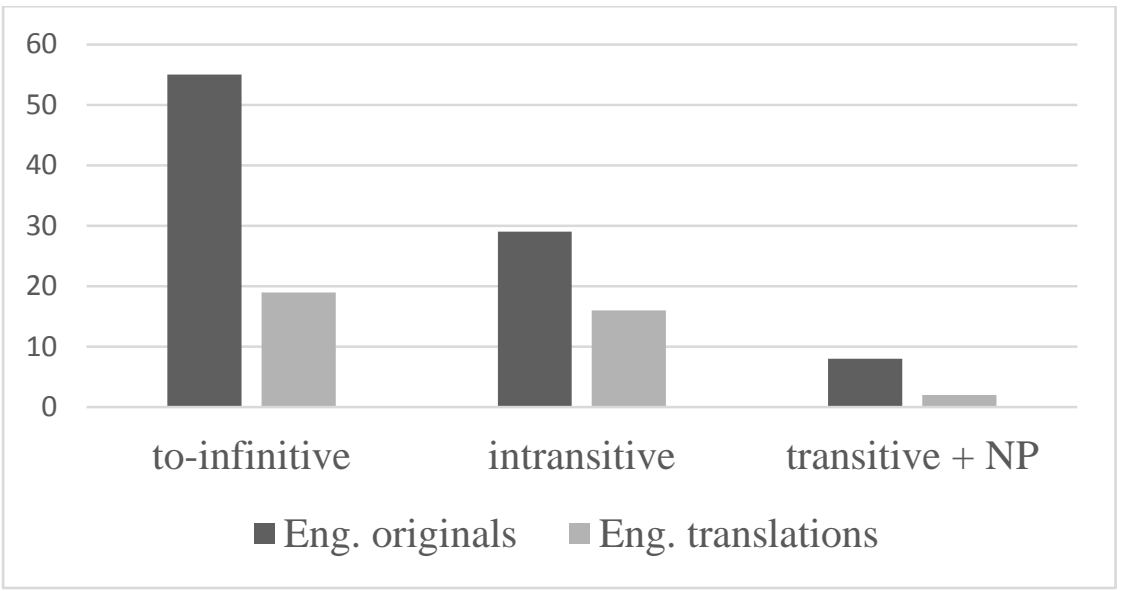

Figure 1: Raw numbers of instances of FAIL in three constructions.

As shown by Figure 1, in all three of the main syntactic roles of FAIL, intransitive, transitive with a nominal (frequently reflexive) object and as a matrix verb with a to-infinitive complement, there are considerably more instances in the English originals, confirming one of two hypotheses outlined in section 1 . Why do we find fewer instances of all three in the English translations than originals? With respect to the FAIL TO construction, we will see in sections 4.2 and 4.3 that the expenditure of unsuccessful effort tends to be coded in Norwegian by constructions containing a verb denoting effort combined with the negative particle $i k k e$, corresponding, for example, to 'did not manage' in English. The maximally congruent, and by far the most common, form of English translation of such phrases contains not in place of Norwegian ikke. The same point may be made about the other two constructions, exemplified here by (12) and (13).

(12) Maybe she was one of those women who succeeds in business and fails in relationship with men. (SG1)

Kanskje hun var en av de kvinnene som lykkes i karrieren og ikke får til sine forhold til menn. (SG1T)

"...does not succeed in..."

(13) Kate failed her eleven plus. (MD1)

Kate klarte ikke opptagelsesprøven til høyeste kursplan på ungdomsskolen... (MD1T)

"...did not manage..."

If we restrict our attention to instances of the FAIL TO construction, and inquire as to the distribution of the four main semantic types in the English originals and translations, we find that the Effort type is the most common in the translations, while the Negation type is most common in the originals. Since, as is shown in Figure 1, there are more than twice as many instances of FAIL TO in the English original texts, the incidence of the four semantic types is given in Figure 2 in percentages rather than raw figures, for ease of comparison. 


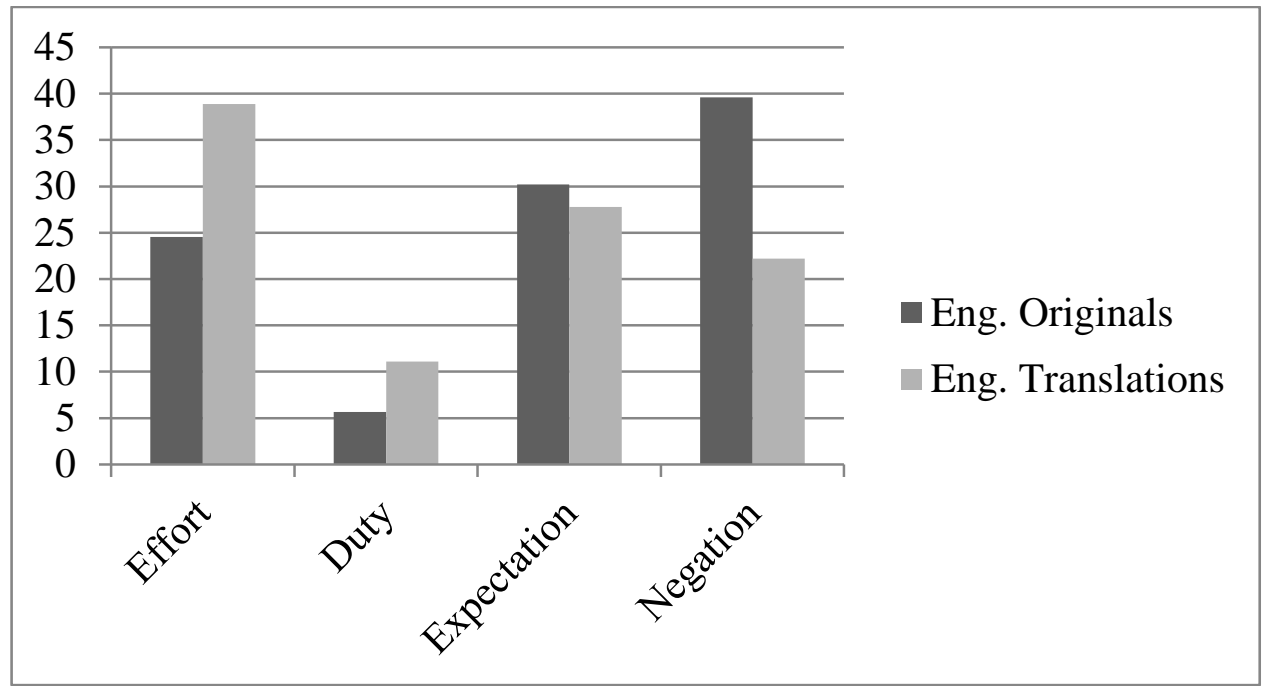

Figure 2. Percentages of four semantic types in English originals and translated FAIL TO.

In sections 4.2 and 4.3 we will look more closely at the translation correspondences of the various senses of FAIL TO.

\subsection{Translations of English originals}

There are 55 instances of FAIL TO in the English original texts in the ENPC. Instances of the construction are found in just under half of the texts in the corpus (24 out of 50). Their translation correspondences are listed in Table 1, in which near-synonyms are grouped together.

Table 1. Main Norwegian correspondences of English original FAIL TO.

\begin{tabular}{|l|l|c|}
\hline Form of translation & Meaning & Instances \\
\hline ikke (+ hverken) & not (+ neither) & 21 \\
\hline ikke klare, ikke greie, ikke få, mislykkes i, ikke lykkes i & not manage & 16 \\
\hline (ikke) unngå & (not) avoid & 6 \\
\hline ikke makte, være ute av stand til & be unable & 3 \\
\hline unnlate & omit & 2 \\
\hline glemme & forget & 2 \\
\hline nekte & refuse & 1 \\
\hline gi opp & give up & 1 \\
\hline aldri slutte & never stop & 1 \\
\hline være nødt til & have to & 1 \\
\hline$\varnothing$ & & 1 \\
\hline
\end{tabular}

The fact that as many as 21 of 55 instances of FAIL TO are translated by either ikke or hverken ('neither') may be taken as a first indication of support for the hypothesis in section 1 that FAIL TO may be translated by pure negation markers. Since FAIL TO, in all of its senses, always precludes the realisation of the situation in its complement clause, it is no surprise that most of its translation correspondences display negative implicatures. The two exceptions, aldri slutte ('never stop') and vare nødt til ('have to'), which both imply the realisation of the complement situation, are used to translate negated FAIL TO. Example (14) may serve as an illustration. 
(14) On the one hand, she cannot fail to feel respect for her father's achievements... (MD1)

På den ene siden er hun nфdt til ̊̊ ha respekt for det faren har oppnådd. (MD1T) "...she needs to..."

Similarly, the single token with a zero correspondence, (15), translates negated FAIL TO.

(15) It was a sight that made me think of warm kitchens and well-seasoned stews, and it never failed to make me ravenous. (PM1)

Det var et syn som fikk meg til å tenke på varmen på kjøkkenet og duftende lapskaus og gjorde meg skrubbsulten! (PM1T)

"... and made me ravenous."

Readers familiar with Norwegian may wonder why ikke makte is classified as indicating lack of ability, rather than unsuccessful effort. The reason is that in the single example of this construction in the corpus, cited here as (16), maktet ikke translates the Expectation rather than the Effort sense of FAIL TO.

(16) But today even this wonder, continually repeated, failed to comfort his spirit. (PDJ3) Men i dag maktet selv ikke dette underet, som gjentok seg gang på gang, å gi ham ro i sinnet. (PDJ3T)

"...was unable to..."

It is obvious that the subject in (16), this wonder, is not agentive; i.e. that it did not try to comfort the spirit of the person in question. There is rather an implication of disappointed expectation on his part.

If we make a crude distinction between the instances in which FAIL TO codes mere negation, or affirmation in the case of (15), and instances where there is an additional implication of Effort, Duty or Expectation, we find that translations either add or subtract such implications in about a third of all cases, indicating perhaps that the alleged semantic distinctions are not felt as keenly by translators as by the present linguist, at least. I will exemplify with some instances containing the implication of effort, starting with instances (17) and (18) where this implication is present in the original and preserved in the translation.

(17) He believed that the reason he had failed to win the girl ... (RF1)

... at han ikke hadde klart å vinne piken... (RF1T)

"...had not managed to..."

(18) ... which the air forces failed to destroy by bombardment. (DL2)

... som flyvåpenet ikke greide å ødelegge med bombing... (DL2T)

"...did not manage to..."

The Norwegian matrix verbs in (17) and (18) both imply the expenditure of effort on the part of the subject to realise the complement situation. We may contrast these with the simple negation in the translation in (19). 
(19) He failed to get this and was instead matriculated as an Arts 11 student... (RF1) Dette fikk han ikke... (RF1T)

"This he did not get..."

The this in (19) refers to a scholarship and, since these are generally viewed in a positive light by prospective students, the translator may have felt it unnecessary to indicate the expenditure of effort to achieve this award on the part of the subject. ${ }^{4}$

We see an example of the opposite tendency, i.e. the addition of the implication of effort, in (20).

(20) We need the concrete and real, as he did; and we fail to see this.... (OS1)

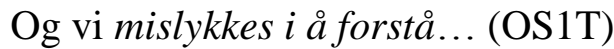

"And we do not succeed in understanding...'

In (20) there is no implication that the subject (we) makes any effort to incorporate the 'concrete and real' into our conception of the cognitive sciences, the topic dealt with in the text from which the example is taken. It merely states that we do not do so. It is the translator who adds the implication of the expenditure of effort.

Unlike (20) the majority of translations of Negation FAIL TO do not add implications of effort. (21) is representative of these translations.

(21) These intense areas automatically draw the eyes of the predator and as he stares at them he fails to notice the larger shape which carries them. (DM1)

Disse iøynefallende områdene tiltrekker seg automatisk rovdyrets blikk, og når et stirrer på dem, legger det ikke merke til den større formen de befinner seg på. (DM1T)

"...does not notice..."

It is instances like (21) that provide the clearest indication that the translator in question has taken FAIL TO to code negation, and nothing more.

\subsection{Translations of Norwegian originals}

Table 2 contains details of the instances in the original Norwegian texts that are translated by English FAIL TO. The 18 instances are found in 12 texts. $^{5}$

\footnotetext{
${ }^{4}$ We may note in passing that 'ikke få' codes negative implicature when employed as a matrix verb with a past participle complement. This is the case when failed to deposit (JB1) is translated as fikk ikke deponert.

${ }_{5}^{5}$ have omitted one token from the analysis, since the original Norwegian text contains a quotation in English naturally rendered verbatim in the English translation.
} 
Table 2. Main Norwegian correspondences of FAIL TO in English translations.

\begin{tabular}{|l|l|c|}
\hline Form of original & Meaning & Instances \\
\hline ikke, ingenting & not & 8 \\
\hline unnlate, la være & omit to & 3 \\
\hline ikke greie & not manage to & 2 \\
\hline uten (NP) & without (NP) & 2 \\
\hline utebli, ryke ut & other (intrans), & 2 \\
\hline$\varnothing$ (translated by negated fail to) & $\varnothing$ & 1 \\
\hline
\end{tabular}

(22) Men jeg greidde visst ikke å få det forklart. (KF1)

"...did not manage to..."

But apparently I failed to make her understand. (KF1T)

Eight of the instances mark negation either by ikke, as in (23), or the negative pronoun ingenting ('nothing'). ${ }^{6}$

(23) Hvis ikke den utlagte faren erkjenner farskapet. (LSPL1)

"...does not acknowledge..."

If the putative father fails to acknowledge paternity... (LSPL1T)

In (23) both the original Norwegian text and its English translation instantiate negation, pure and simple, there being no reason to expect the putative father to acknowledge paternity. Indeed quite the opposite is the case, as indicated by the heading of the text section from which the sentence is taken: "Establishment of paternity by a court decision".

The majority of translations resemble (22)-(23) in that they neither add nor subtract implications present in the original formulations. Indeed, there are no cases in which an implication of effort, duty or expectation is subtracted. This follows largely from the fact that most of the Norwegian originals denote negation pure and simple, there being thus no implications to subtract. There are, however, four instances in which implications are added (or at least formalised), three involving Effort, and one Duty. Two of the cases where an implication of effort is added take the form of a construction in Norwegian consisting of the preposition uten (without) followed by a noun phrase, as in (24).

(24) Det hadde imidlertid liten virkning, for ved valget i 1989 endte det samlede Venstre igjen uten mandater til Stortinget. (UD1)

"...without seats in parliament..."

This had little effect, for after the 1989 election, the new Liberal Party failed to win a single seat in the national assembly. (UD1T)

It is, of course, natural to assume that a political party taking part in a parliamentary election will endeavour to win seats in parliament, but our understanding of this effort is based on our knowledge of contemporary politics and government in the case of the Norwegian original in (24). It is more directly implied in the English translation.

\footnotetext{
${ }^{6}$ To these may be added the non-negated Norwegian original ...alle hadde naturligvis lagt merke til... (EG1), which merely states "naturally everyone had noticed", but which is translated ...no one could have failed to notice...
} 

(25).

The token in which a dereliction of duty is implied in the translation is cited here as

(25) De anså det hele for å være en fillesak og sikret seg ikke navn og adresse på noen av vitnene. (KA1)

"...did not get hold of..."

They saw the whole thing as a trivial case and failed to take the names and addresses of any of the witnesses. (KA1T)

Whereas the Norwegian original in (25) merely asserts that they (the police) did not note the names and addresses of witnesses, the English translation implies neglect on their part in not so doing.

\section{Summary and conclusions}

The purpose of the study reported on in this article was to determine whether translation correspondences of the FAIL TO construction could lend support to the contention that this construction is now functioning, in at least some contexts, as a marker of negation pure and simple. The translation correspondences examined were Norwegian, and the data, consisting of translations both from and into English, were taken from the English-Norwegian Parallel Corpus.

Two hypotheses were advanced in section 1 . The first predicted that there were likely to be more instances of FAIL TO in the English original texts than in the translations into English. The reasoning behind this hypothesis was the assumption that, if FAIL TO is actually functioning as a negation marker, translators into English of Norwegian negative predications would be more likely to employ the default negation marker not than a periphrastic negative. The second hypothesis was that if FAIL TO is indeed functioning as a periphrastic negative, we should expect to find instances translated by the default Norwegian negation marker ikke, and possibly also examples where FAIL TO is used to translate $i k k e$.

Before presenting the results of the corpus study, I looked, in section 3, at some English language-internal evidence that FAIL TO can function as a negation marker. I also touched on the question of whether the construction has grammaticalised in English and argued that Negation FAIL TO has evolved from Expectation FAIL TO with the gradual bleaching of the element of speaker expectation in the course of the last couple of centuries.

Section 4 contained an overview of the results of the corpus study. The data show clearly that FAIL TO is three times as common in original English than translated texts, thus lending support to the first hypothesis. The reason for this discrepancy is presumably that not is the default translation correspondence of negated Norwegian expressions. The second hypothesis is supported by the results presented in sections 4.2 and 4.3, which show that FAIL TO is often translated by, and used to translate, the Norwegian negation marker ikke. The fact that it can be used to translate ikke is particularly strong evidence of its function as a periphrastic negative since the translator into English has chosen it in place of the default negation marker not.

In conclusion, the results presented in this article add inter-linguistic evidence of the negative character of FAIL TO to the sort of intra-linguistic evidence mentioned in section 3 . If one accepts that the more evidence one has, and the more different sorts of evidence, the better, it is clear that in some contexts FAIL TO fails to mean more than not. 


\section{References}

Secondary sources:

Bolinger, D. 1977. Meaning and Form. London: Longman.

Boye, K. and Harder, P. 2009. Evidentiality: Linguistic categories and grammaticalization. Functions of Language 16(1): 9-43.

Boye, K. and Harder, P. 2012. A usage-based theory of grammatical status and grammaticalization. Language 88(1): 1-44.

Diewald G. 2010. On some problem areas in grammaticalization studies. In Grammaticalization: Current Views and Issues, K. Stathi, E. Gehweiler and E. König (eds), 17-50. Amsterdam: John Benjamins.

Dixon, R. M. W. 2012. Basic Linguistic Theory: Volume 3: Further Grammatical Topics. Oxford: Oxford University Press.

Egan, T. 2008. Non-finite Complementation: A Usage-based Study of Infinitive and -ing Clauses in English. Amsterdam: Rodopi.

Egan, T. 2010. The 'Fail to' construction in Late Modern and Present-day English. In English Historical Linguistics 2008. Selected Papers from the Fifteenth International Conference on English Historical Linguistics. Volume 1: The History of English Verbal and Nominal Constructions, U. Lenker, J. Huber and R. Mailhammer (eds), 123-141. Amsterdam: John Benjamins.

Egan, T. 2016. The subjective and intersubjective uses of FAIL TO and 'not fail to'. In Aspects of Grammaticalization: (Inter)subjectification and Pathways of Change, H. Cuyckens, L. Ghesquière and D. van Olmen (eds), 168-196. Berlin: De Gruyter.

Horn, L. 2001. A Natural History of Negation. Reissued with new introduction. Stanford, CA: Center for the Study of Language Information.

Huddleston, R. D. and Pullum, G. K. 2002. The Cambridge Grammar of the English Language. Cambridge: Cambridge University Press.

Johansson, S. 1997. In search of the missing not: Some notes on negation in English and Norwegian. In From Alfric to the New York Times: Studies in English Corpus Linguistics, U. Fries, V. Müller, and P. Schneider (eds), 197-214. Amsterdam: Rodopi.

Johansson, S. 2007. Seeing through Multilingual Corpora: On the Use of Corpora in Contrastive Studies. Amsterdam: John Benjamins.

Karttunen, L. 1971. Implicative verbs. Language 41. 340-358.

Kranich, S. 2010. Grammaticalization, subjectification and objectification. In Grammaticalization: Current Views and Issues, K. Stathi, E. Gehweiler and E. König (eds), 101-121. Amsterdam: John Benjamins.

Langacker, R. 2008. Cognitive Grammar: A Basic Introduction. Oxford: Oxford University Press.

Mackenzie, J. L. 2008. Failing without trying. Jezikoslovlje 9(1-2): 53-85.

Quirk, R., Greenbaum, S., Leech, G. and Svartvik, J. 1985. A Comprehensive Grammar of the English Language. London: Longman

Traugott, E. C. 2010. (Inter)subjectivity and (inter)subjectification: A reassessment. In Subjectification, Intersubjectification and Grammaticalization, K. Davidse, L. Vandelotte and H. Cuyckens (eds), 29-7. Berlin: De Gruyter.

Traugott, E. C. and Dasher, R. B.. 2002. Regularity in Semantic Change. Cambridge: Cambridge University Press. 
Thomas Egan

Primary sources:

CLMET: Corpus of Late Modern English Texts. De Smet, H. 2005. ICAME Journal 29, 69-82.

NODE: The New Oxford Dictionary of English, J. Pearsall and P. Hanks (eds). 1998. Oxford: Oxford University Press.

OED: The Oxford English Dictionary, $2^{\text {nd }}$ edition on compact disc. 1992. Oxford: Oxford University Press

ENPC: The English-Norwegian Parallel Corpus. Oslo: Oslo University: see $<$ http://www.hf.uio.no/ilos/english/services/omc/enpc/>.

WebCorp: Birmingham: Birmingham City University: see <http://www.webcorp.org.uk/live/>

Author's address:

Thomas Egan

Inland Norway University of Applied Sciences

Holsetgata 31

2318 Hamar

Norway

thomas.egan@inn.no 